\title{
Müzik Dinlemenin Arapça Öğretiminde Kullanılmasının Öğrencinin Akademik Başarısına Etkisi ${ }^{1}$
}

\author{
Şeyma ÖZCAN \\ Milli Eğitim Bakanlığ \\ seyma.ozcan@gazi.edu.tr \\ Musa YILDIZ \\ Gazi Üniversitesi \\ ymusa@gazi.edu.tr
}

Gönderilme Tarihi: 07/05/2020

Kabul Tarihi: $28 / 11 / 2020$

Yayınlanma Tarihi: 12/11/2020

DOI: $\underline{10.30855 / \text { gjes.2020.06.03.001 }}$

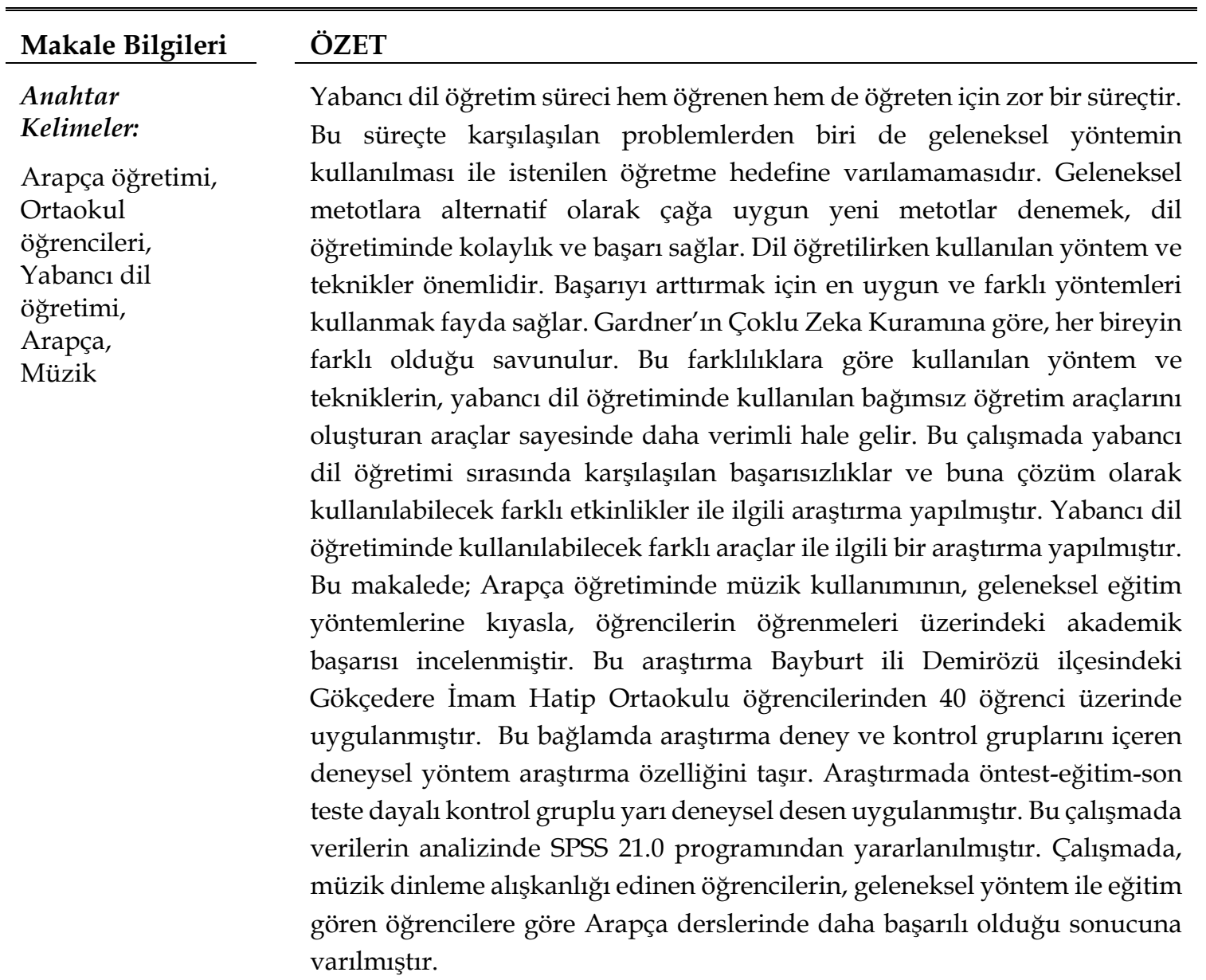

${ }^{1}$ Bu araştırma Prof. Dr. Musa YILDIZ danışmanlığında yürütülen Şeyma ÖZCAN'ın yüksek lisans tezinden üretilmiştir.

Özcan, Ş., \& Yıldız, M. (2020). Müzik dinlemenin Arapça öğretiminde kullanılmasının öğrencinin akademik başarısına etkisi. Gazi Ĕ̆itim Bilimleri Dergisi, 6(3), 261-276.

DOI: https://dx.doi.org/110.30855/gjes.2020.06.03.001

Dergi Web Sayfası: http://dergipark.gov.tr/gebd 


\section{The Effect of Using Listening to Music in Arabic Teaching on the Academic Success of the Student}

\begin{tabular}{ll}
\hline \hline Article Info & ABSTRACT \\
\hline Keywords: & Foreign language teaching process is a difficult process for both learner \\
Arabic teaching, & and teacher. One of the problems encountered in this process is the \\
Middle school & failure to reach the desired teaching goal by using the traditional \\
students, & method. Trying new age-appropriate methods as an alternative to \\
Teaching foreign & traditional methods provides ease and success in language teaching. \\
language, & The methods and techniques used while teaching the language are \\
Arabic, & important. It is beneficial to use the most appropriate and different \\
Music & methods to increase success. According to Gardner's Multiple \\
& Intelligence Theory, everyone is claimed to be different. The methods \\
& and techniques used according to these differences become more \\
& efficient thanks to the tools that make up the independent teaching tools \\
& used in foreign language teaching. In this study, research about the \\
& failures encountered during foreign language teaching and different \\
& activities that can be used as a solution to this have been conducted. A \\
& research has been done on different tools that can be used in foreign \\
& language teaching. In this research, the academic success of the use of \\
& music in Arabic teaching compared to traditional education methods \\
& has been examined. This research was applied on 40 students of \\
& Gökçedere Imam Hatip Middle School students in Demirözü district of \\
& Bayburt province. In this context, the experimental method, which \\
includes the experimental and control groups, has the feature of & research. In the research, a quasi-experimental pattern with control \\
group based on pretest-training-posttest was applied. In this study, \\
SPSS 21.0 program was used to analyze the data. In the study, it is \\
concluded that students who have the habit of listening to music are \\
more successful in Arabic lessons than students who are educated with \\
traditional method.
\end{tabular}

\section{Gíriș}

İçinde bulunduğumuz yirmi birinci yüzyılda bilim ve teknoloji başta olmak üzere tüm alanlarda sürekli değişme ve yenileşme ile birlikte söz edilen kavram bilgi toplumudur. Bilgi toplumunda ise iletişim bilhassa kitle iletişim araçları ve internet bu toplum yapısının vazgeçilmezleri arasında sayılmaya başlanmıştır (Arklan ve Taşdemir, 2008). Toplumlar arası iletişimin en önemli unsuru olan dil ise bilgi toplumunda insanların mutlaka ileri seviyede sahip olması gereken bir araçtır. Farklı kültür ve toplumlarla sürekli iş birliğinde olan bizlerin ise karşılaşttğı en büyük problem yabancı dil öğrenme sürecidir. İşeri'ye (1996) göre yabancı dil öğrenmek sadece o dili konuşmak değil, aynı zamanda o dili kullanan toplulukla duygu, düşünce ve kültür alışverişinde de bulunmak demektir. Ancak, bir yabancı dilin öğrenimi ve öğretimi 
öğrencilerin o dile yeni ve yabancı olmalarından dolayı pek kolay olmamaktadır. Bunun yanında, yabancı dil öğrenen bireylerin sahip oldukları bireysel farklılıklar da yabancı dil öğrenme sürecinde önemli etkilere sahip olabilmektedir (Aydin ve Zengin, 2008).

Yabancı dil öğretme ve öğrenme ihtiyacı, tüm dünyada olduğu gibi ülkemizde de önemle üzerinde durulan güncel bir konudur. Fakat bu ihtiyacın giderilmesi konusunda birçok sorunla karşı karşıya olduğumuzu da söylemek gerekir. Çünkü ülkemizde yabancı dil öğretimine ilköğretimden üniversitenin son sınıfına kadar ortalama 12 yıl boyunca saatlerce zaman ayrılmasına rağmen yine de tatmin edici bir sonuç elde edilememektedir. Yabancı bir dili öğrenirken öğrenciler kurallarla, açıklamalarla ve kendilerini ilgilendirmeyen, onlara yabancı olan konularla ilgilenmezler. Süreç boyunca öğrencilerin en çok karşılaştıkları ise hedef dilin dilbilgisi yapısı ve ders esnasında uygulanan öğrencilerin ilgilerini çekmeyen etkinlikler ve çalışmalardır. Oysa ki çocukların farklı olana karşı meraklı ve ilgili oldukları bilinmektedir. Bu ilgi farklı yerler, kültür ve dillere karşı da söz konusudur. Öğrencilerin monoton bir ders ortamından çıkarmak da öğrenmeyi kolaylaştıran etkenlerden biridir.

Birden çok duyu organına hitap eden araçların yabancı dil öğretiminde kullanımı hem öğrenimi hızlandırmakta hem de bilginin uzun süre kalıcı olmasını sağlamaktadır (Koç, 2018). Öğrencilerin ilgilerini oyunlar, şarkılar, tekerlemeler, masallar ve çizgi filmler çeker. "Sanatçılar tarafından yapılmış özgün resimler, karikatürler, klasik müzik çalışmaları, kısa filmler, görselişitsel araçlar metinlerin iletilerine yeni yorumlar, açılımlar katarak çok uyaranla bir öğrenmeöğretme ortamının yaratılmasına olanak sağlamaktadır" (Turhan Ağrelim, 2016:18). Yabancı dil öğretimi sırasında ise öğrencilerin motivasyonlarını arttıracak etkinlikler yapmak örneğin çizgi film, oyunlar, müzikler ve görsel-işitsel etkinlikler, biz yabancı dil öğreticilerine süreçte fayda sağlayacaktır ve öğrenci motivasyonunu arttıracaktır. Bu sayede başarı oranı da artacaktır. Çünkü motivasyon, başarılı bir öğrenmenin gerçekleşmesi için anahtar bir faktördür (Reece ve Walker, 1998).

Öğrencilerin öğrendikleri yabancı dilde hizmet veren kanalların ve televizyon programlarının da yabancı dil öğrenmeye etkisi olabilmektedir. Öğrenmenin en iyi doğal ortamında gerçekleştiği bilinen bir gerçektir fakat bunun mümkün olmadığı ortamlarda doğal ortamın yansıtıldığı görsel-işitsel araçlardan faydalanılabilir. Özellikle dil öğretiminde, dilin kendi doğal ortamından yararlanılmasının büyük bir katkısı olabileceği bilinmektedir. Bunun mümkün olmadığı durumlarda ise doğal ortamı oluşturmak hedef dildeki müzikler ile gerçekleştirilebilir. Yabancı dil öğretimi sırasında kolaylıkla ulaşabileceğimiz hedef dildeki müzikler sayesinde, öğrencilerin motivasyonlarını arttırabiliriz. Yabancı dilde dinlenilen müzikler, öğrencilerin dinleme ve anlama becerilerini geliştirmelerine de katkı sağlamaktadır. Öğrenciler eğlenceli buldukları müzikler ile daha hızlı ve kalıcı bir şekilde öğrenirler. Müziklere 
duydukları ilgi onları öğrenmeye sevk eder. Kulak-dil alışkanlığı yönteminden de bildiğimiz üzere, amaç dildeki sözcükler o dili konuşanlar için taşıdıkları anlamda ve kültürel bağlamda öğrenilmelidir (Demirel, 2004). Yani kulak-dil eğitimine verilen önem bizlere fayda sağlayacaktır. Hedef dilde kullanılan şarkılar, öğrencinin dinlediğini anlama becerisine olumlu bir katkıda bulunur. Şarkıların tekrarlı bir biçimde öğrencilere dinletilmesi ve bunun yanında boşluk doldurma, dinleme ve çizme gibi alıştırmaların yapılması sırasıyla öğrencilerin hem duyduğunu algılamasına hem de dinlediğini anlamasına yardımcı olur. Son olarak şarkılar kelime dağarcığının artırılması ve konuşma becerisinin geliştirilmesi noktasında da etkili bir materyal olabilir. Çaydere (2006) dil gelişimi ve okuma eğitiminde müziğin etkisini araştırdığ çalışmasında, okuma-dil-müzik eğitimi bağlantısında yapılan araştırmaları incelemiştir. Müziğin çocukların bireysel dil gelişimlerinde önemli bir araç olduğunu ortaya koymuştur. Bu nedenle işitsel araçlardan müzik, öğrencinin yabancı dil öğrenimine etki edebilir.

Araştırmanın Amacı ve Önemi

Müziğin Arapça öğreniminde kullanılmasının öğrencinin akademik başarısı üzerindeki etkisinin incelenmesidir.

Öğrencilerin Arapça dilini öğrenirken karşılaştıkları problemleri müzik ile aşabilme imkanları, onların akademik başarılarını olumlu yönde etkiledikleri için önemli bir rol oynar. Bu bağlamda araştırmanın alt problemleri şunlardır:

1. Deney grubu ile kontrol grubu öğrencilerinin akademik başarı ön test puanları açısından aralarında anlamlı düzeyde farklılık var mıdır?

2. Deney grubu ile kontrol grubu öğrencilerinin akademik başarı son test puanları açısından anlamlı düzeyde farklılık var mıdır?

\section{YÖNTEM}

Araştırmada öntest-son teste dayalı kontrol gruplu yarı deneysel desen uygulanmıştır. Gruplardan biri deney diğeri ise kontrol grubu olarak belirlenmiştir. İki grupta yer alan öğrencilerin Arapça bilgi düzeylerini ölçmek amacıyla ön-test uygulanmıştır. Kontrol grubuna geleneksel yöntemler ile deney grubuna ise müzik kullanırak eğitim verilmiştir. Uygulamanın sonunda gruplar son teste tabi tutulmuşlardır.

\section{Çalışma Grubu}

Bu çalışma, 2019-2020 Eğitim-Öğretim yılında Bayburt ili, Demirözü ilçesi Gökçedere İmam Hatip Ortaokulu 5. Sınıf şubelerinde gerçekleştirilmiştir. Analizler kontrol grubunda 20, deney grubunda 20 olmak üzere toplam 40 öğrencinden elde edilen veriler ile yapılmıştır. 


\section{Değişkenler}

Bu çalışmanın bağımsız değişkeni öğrencilere müzik kullanılarak eğitim verilmesidir. Bağımlı değişkeni ise öğrenci başarısıdır.

\section{Veri Toplama Araçları}

Öğrenci başarılarını ölçmek için deney ve kontrol gruplarına araştırmacı tarafından bir akademik başarı testi geliştirilmiştir. İki gruba da "Harfler", "Rakamlar", "Renkler", "Vücudun Bölümleri", "Aile Üyeleri” konularında bilgi ve becerilerini test eden 19 sorudan oluşan bir öntest uygulanmıştır. Aynı test, uygulama sonrası gruplara son-test olarak uygulanmıştır.

\section{İşlem Basamakları}

Araştırmada kullanılacak müzikler, kazanımlar göz önünde bulundurularak hazırlanmıştır (Ek. 1). Bu etkinlikler; deney grubuna uygulanırken, kontrol grubunda aynı konular geleneksel yöntemler kullanılarak öğretilmiştir.

\section{Verilerin Analizi}

Bu çalışmada verilerin analizinde SPSS 21.0 programından yararlanılmıştır. Karşılaştırma testlerinde parametrik ve non-parametrik testlerden hangisinin kullanılacağını belirlemek amacıyla grup örneklemi dikkate alınarak $(\mathrm{N}<50)$ Shapiro-Wilk testinden yararlanılmıştır. Shapiro-Wilk testine ait $\mathrm{p}$ değerinin her iki grupta da 0,05'ten büyük olması grup ortalamalarının normal dağılım gösterdiğini; herhangi bir grupta $p<0,05$ olması durumunda dağılımın normal olmadığı anlaşılmaktadır (Büyüköztürk, 2011).

\section{BULGULAR}

Kontrol ve deney grubundaki öğrencilerin etkinliklere başlamadan önce ön-test başarı puanları arasındaki farkın anlamlı olup olmadığı ortaya koymak için yapılan Mann Whitney U testi bulgularına yer verilmiştir.

\section{Tablo 1.}

Deney ve Kontrol Gruplarının Başarı Ön Test Puanlarının Karşılaştırılması

\begin{tabular}{lcccccc}
\hline Grup & N & $\overline{\mathbf{X}}$ & $\mathbf{S}$ & sd & $\mathbf{Z}$ & $\mathbf{p}$ \\
\hline Deney & 20 & 14,75 & 8,19 & 38 & $-1,65$ & 0,099 \\
Kontrol & 20 & 18,75 & 7,23 & & & \\
\hline
\end{tabular}

Tablo 1'de görüldüğü gibi Arapça başarı testi ön test puanlarının gruplara göre anlamlı farklılık göstermediği $(\mathrm{p}>0,05)$ tespit edilmiştir.

Tablo 2'de deney ve kontrol gruplarının Arapça başarı testi son test puanlarının karşılaştırılmasına ait Mann Whitney $\mathrm{U}$ testi bulgularına yer verilmiştir. 
Tablo 2.

Deney ve Kontrol Gruplarmın Başarı Son Test Puanlarının Karşılaştırılması

\begin{tabular}{lccccrc}
\hline Grup & N & $\overline{\mathbf{X}}$ & $\mathbf{S}$ & sd & $\mathbf{Z}$ & $\mathbf{p}$ \\
\hline Deney & 20 & 64,75 & 21,67 & 38 & $-2,28$ & 0,023 \\
Kontrol & 20 & 46,50 & 23,00 & & & \\
\hline
\end{tabular}

Arapça dersine yönelik geliştirilen başarı testi puanlarının gruplara göre anlamlı farklılık gösterdiği tespit edilmiştir $(Z=-2,28 ; p<0,05)$. Deney grubunun Arapça dersine yönelik geliştirilen başarı testi puanları, kontrol grubu puanlarına göre anlamlı düzeyde daha yüksektir.

\section{TARTIŞMA VE SONUÇ}

Dinleme ve konuşma becerisi yabancı dil öğretiminde dört temel beceriden ikisi olan ve öğrencilerin duyduklarını doğru bir şekilde anlayıp ifade etmesini sağlayan önemli iki beceri olarak sayılıyor olsa da öğrenciler bu konuda oldukça zorlanmaktadır. Birey yabancı dili ne kadar iyi okusa ve yazsa da eğer dinlediğini anlayıp cevap veremiyorsa tam olarak o dili öğrenmiş sayılmaz. Yaptı̆̆ımız araştırmanın sonucunda, yabancı dil öğrenirken şarkı dinleyerek, öğrenime destek olunduğunda, öğrencilerin başarılarının arttığı görülen bir gerçektir. Araştırma sonuçları incelenecek olursa, Arapça dersine yönelik geliştirilen Arapça Akademik Başarı Testi puanlarının, müzik kullanılarak eğitim verilen öğrencilerin, kontrol grubundaki geleneksel yöntem ile eğitim gören öğrencilere göre anlamlı düzeyde daha yüksek olduğu saptanmıştır. Geleneksel yöntemlerden uzaklaşarak Arapça öğretiminde müziğin kullanılması, Arapça dersi başarısı üzerinde anlamlı derecede olumlu bir etki oluşturmuştur.

Yabancı dil derslerinin, monotonluktan uzak, eğlenceli bir ders olması, yeni yaklaşımlar ve metotlarla işlenmesi, özellikle ezbercilikten uzak, görsel-işitsel-dokunsal tüm becerilerin aktif kullanıldığı bir ders ortamının oluşturulması ve buna uygun materyaller seçilerek işlenmesi gerekmektedir (Gömleksiz ve Elaldı, 2000). Dinlenilen şarkılar ise bu konuda bize fazlasıyla yardımcı olmaktadır.

Yabancı dil öğretiminde dikkat edilmesi gereken, genel kabul görmüş bazı temel ilkeler vardır. Bunlardan araştırmamız ile ilgili olanlar Demirel (2004) tarafından şöyle ifade edilmiştir:

1) Öğretime dinleme ve konuşma becerilerini geliştirme ile başlanmalı,

2) Öğrencilerin temel cümle kalıplarını öğrenmesinin ve ezberlemesinin sağlanması,

3) Kullanılan dilin öğretilmesi,

4) Öğrencilerin yeni dil kazanma alışkanlıkları sağlamasına yardımcı olunması,

5) Öğrencilerin dilin seslerini en iyi şekilde çıkarmalarının öğretilmesi,

6) Amaç dilin o dili ana dili olarak konuşan kişilerin konuştuğu gibi öğretilmesi. 
Buradan da anlaşılabileceği gibi temel ilkeleri, yabancı dil öğretimi sürecinde müzik kullanarak uygulanmaktadır. Müzik sayesinde öğrenciler gündelik konuşma kalıplarını tekrarlar halinde duyarak öğrenirler. Arapça gibi harflerinin düzgün çıkarılması gereken bir dilde, seslerin daha sağlıklı çıkarılmasına yardımcı olur. Çünkü telaffuzun güzelliği öğrencinin yeteneğinin yanı sıra kulak aşinalığı ile de gelişir. En önemlisi ise dil öğretimi sırasında yaratılamayan doğal öğrenme ortamlarının, müzik ile sağlanmasıdır.

Dale' nin yaşantı konisinin dayandığı ilkelerden biri olan" Öğrenme işlemine katılan duyu organlarımızın sayısı ne kadar fazla ise, o kadar iyi öğrenir ve öğrenmelerimiz o kadar kalıcı olur." ilkesi bizlere dil öğretiminde video vb. destekleyici materyallerle öğrencilerin daha kalıcı öğrenmeler edineceğini söylemektedir. Arapça öğrenirken müzik dinleyen çocuklar hem duyarak hem de söyleyerek öğrenmeyi kalıcı hale getirir. Burada önemli olan öğreticilerin, öğrencileri dinleyecekleri şarkılar konusunda doğru yönlendirmeleri gerektiğidir. Çünkü Arapça birçok lehçe türü olan bir dildir ve öğrencilerin hedef dili öğrenirken bu dilin en saf halini yani fasih halini öğrenmeleri onların yararına olacaktır. Öğrenci Arapçayı direk o dili ana dil olarak konuşan kişilerin konuştuğu gibi duyduğu için öğretim daha sağlıklı ve başarılı olur.

\section{ÖNERILER}

Öğrencilerin de birer çocuk olduğunu unutmadan yabancı dil öğretme sürecinde onlara izlettiğimiz görsel-işitsel materyaller sayesinde hedef dile karşı tutumlarını olumlu yönde arttığını görmek, süreç sırasında müziği kullanmanın faydalı olduğunu bizlere göstermiştir. Çilek'in (2017) de dediği gibi, Arapça dersi öğretmenleri dinlemenin bir beceri olduğunu fark etmeleri ve uygulamayla becerilerin geliştirilebileceğine inanması ve buna göre etkinlikleri düzenlemesi gerekmektedir.

Yabancı dil olarak Arapça eğitiminde, dil öğreticilerine düşen görevlerin başında geleneksel yöntemlerden uzaklaşarak, farklı yöntem ve teknikleri deneyerek, uygulamaya koymak olmalıdır. Öğrencilerin ilgilerini çekecek, ders başarısını arttıracak etkinlikler yapılması tavsiye edilmektedir. Ezberci eğitimden kurtulup, eğlenceli ve kalıcı öğrenmeyi sağlamak için yabancı dil derslerinde kullanılan müzik tarzı materyallerin hem öğretmen hem de öğrenciler açısından verimli olacağı düşünülmektedir. Ayrıca yabancı dil olarak Arapça eğitiminde kullanılabilecek uygulamalar konusunda araştırmalar yapılması ve bunların desteklenmesi gerekmektedir.

\section{KAYNAKÇA}

Arklan, Ü., \& Taşdemir, E. (2008). Bilgi toplumu ve iletişim: bilginin yayılması sürecinde kitle iletişim araçları ve internet. Selçuk Üniversitesi İletişim Fakültesi Akademik Dergisi. 5(3), 67-80 
Arapça Alfabe (2011). https://www.youtube.com/watch?v=0xYy3D6zYgY adresinden 19 Ağustos 2019 tarihinde erişilmiştir.

Aydın, S., \& Zengin, B. (2008). Yabancı dil öğreniminde kayg1: Bir literatür özeti. Journal of Language and Linguistic Studies, 4(1), 81-84.

Büyüköztürk, Ş. (2011). Sosyal bilimler için veri analizi el kitabı (14. Baskı). Ankara: PEGEM Akademi.

Öztosun Çaydere, Ö. (2006). Dil gelişimi ve okuma eğitiminde müziğin etkisi. Abant İzzet Baysal Üniversitesi Eğitim Fakültesi Dergisi. 6(3), 131-136.

Çilek, E. (2017). Arapça öğretiminde bilişsel stratejilerin kullanılmasının dinlediğini anlama becerisine etkisi. Dil ve İslam Dünyası Sosyal Araştırmaları Dergisi,4(10),465-479.

Demirel, Ö. (2004). Yabancı dil öğretimi (2. Baskı). Ankara: Pegem A Yayıncılık.

Gömleksiz, M. N., \& Elaldı, Ş. (2000). Yabancı dil öğretiminde kullanılan yöntemler ve yöntem sorunu. Fırat Üniversitesi İlahiyat Fakültesi Dergisi, 5(1), 253-264. 10 Ocak 2017 Araştırmax veri tabanında alınmıştır.

İşeri, K. (1996). Dilin kazanımı ve yabancı dil öğretimi. Dil Dergisi, 43, 21-27.

Koç, C. T. (2018). Arapça öğretiminde müziğin rolü ve ders materyali olarak şarkı kullanımı. Turkish Studies Language/ Literature, 13(20), 561-573

Rakamlar (2011). https://www.youtube.com/watch?v=WBCv9ZgzjqA adresinden 19 Ağustos 2019 tarihinde erişilmiştir.

Renkler (2018). https://www.youtube.com/watch? $\mathrm{v}=\mathrm{zORUo6Lsns} 8 \& \mathrm{t}=39 \mathrm{~s}$ adresinden 19 A ğustos 2019 tarihinde erişilmiştir.

Renkler (2016). https://www.youtube.com/watch?v=AdQCja4MBcY adresinden 19 Ağustos 2019 tarihinde erişilmiştir.

Reece, I., \& Walker, S. (1998). Teaching, training and learning-a practical guide (Third Edition). Great Britain: Business Education Publishers ltd.

Turhan Ağrelim, H. (2016). Çok uyaranlı eğitim ortamlarının öğrencilerin okuduğunu anlama ve yazılı anlatım becerilerine etkisi. Dil Eğitimi ve Araştırmaları Dergisi, 2(3), 16-50.

Etik Kurul: Bu araştırma yüksek lisans tezinden üretildiği için etik kurul kararı zorunluluğu taşımamaktadır. 


\section{EK-1 Uygulama Örnekleri}

\section{Uygulama 1}

Sinıf: 5

Süre: 40 dakika

Kaynaklar / Araç Gereçler: tahta, tahta kalemi, akıllı tahta kullanımı

Yöntem ve Teknikler: Anlatım yöntemi, soru-cevap tekniği, konuyla ilgili şarkının

Ünite Ya Da Konunun Örüntüsü: Arapça alfabenin öğretimi

\section{Hedefler:}

1. Verilen Arapça harfleri doğru telaffuz etme

2. Verilen Arapça harfleri ezbere bilme

\section{Giriş Bölümü}

Dikkat Çekme: Öğretmen öğrencilere daha önceden Arapçaya ait kelime bilip bilmediklerini sorar. Öğrenciler Arapçaya dair hiçbir şey bilmediklerini söylerler.

Güdüleme: Öğretmen öğrencilere derste işleyecekleri konuyla ilgili kısa bir bilgi verir:

“Bugün Arap alfabesini öğreneceğiz.".

Gözden Geçirme: Daha sonra öğretmen, öğrencilere Türkçe ve Arapça alfabe arasındaki farklılık ve benzerlikten bahseder. Öğrencilere Türkçe alfabenin kaç harften oluştuğunu sorar. Cevabı aldıktan sonra Arapça alfabede 28 harf olduğunu vurgular. Türkçedeki bazı seslerin Arapçada bulunmadığını söyler.

\section{Derse Geçiş:}

\section{Dersin İşlenişi:}

-İlk olarak öğretmen öğrencilere aşağıdaki şarkıyı dinletir.

$$
\begin{aligned}
& \text { أب تث } \\
& \text { خ } \\
& \text { دذرز } \\
& \text { س ش ص ض در } \\
& \text { ط طاع } \\
& \text { ف ق كل ل } \\
& \text { من مهو ي }
\end{aligned}
$$

https://www.youtube.com/watch?v=0xYy3D6zYgY

-Alfabe aşağıdaki gibi tahtaya yazılır. Kendisiyle beraber öğrencilerin de yazmalarını ister.

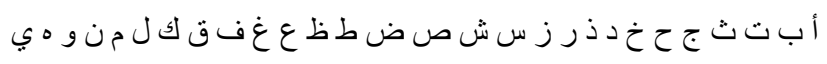

- Şarkı tekrar dinletilir. Duyulan harflerin Türkçe okunuşları birer birer öğrencilerle, tahtaya yazılan harflerin yanına yazılır. 


\begin{tabular}{|c|c|c|c|}
\hline Dad & ض & Elif & i \\
\hline $\mathrm{Ta}$ & $b$ & $\mathrm{Be}$ & ب \\
\hline $\mathrm{Za}$ & ظ & $\mathrm{Te}$ & 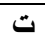 \\
\hline Ayn & $\varepsilon$ & Se & 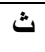 \\
\hline Ğayn & $\dot{\varepsilon}$ & Cim & ج \\
\hline $\mathrm{Fe}$ & ف & $\mathrm{Ha}$ & $\tau$ \\
\hline Gaf & ق & $\mathrm{Ha}$ & $\dot{\tau}$ \\
\hline Kef & S & Dal & د \\
\hline Lam & $J$ & Zel & $\dot{j}$ \\
\hline Mim & p & $\mathrm{Ra}$ & J \\
\hline Nun & ن & Zey & j \\
\hline $\mathrm{He}$ & o & Sin & س \\
\hline Vav & و & Şın & ش ش \\
\hline Ye & ي & Sad & ص \\
\hline
\end{tabular}

-Yazma işlemi bittikten sonra öğrencilere şarkı tekrar dinletilir ve şarkı bittikten sonra tahtaya bakılarak şarkı söylenir.

-Tahtadaki harflerin okunuşları öğrenciler tarafından defterlerine geçirilir.

-Şarkı hep beraber söylenir.

-Şarkıyı söylemek isteyen öğrencilere izin verilir.

\section{Uygulama 2}

\section{Sinif: 5}

Süre: 40 dakika

Kaynaklar / Araç Gereçler: tahta, tahta kalemi, akıllı tahta kullanımı

Yöntem ve Teknikler: Anlatım yöntemi, soru-cevap tekniği, konuyla ilgili şarkının

Ünite Ya Da Konunun Örüntüsü: Arapça rakamların öğretimi

\section{Hedefler:}

1. Verilen rakamları doğru telaffuz etme

2. Verilen rakamları ezbere bilme

\section{Giriş Bölümü}

Dikkat Çekme: Öğretmen öğrencilere daha önceden Arapça rakamları duyup duymadıkları ile ilgili soru sorar.

Güdüleme: Öğretmen öğrencilere derste işleyecekleri konuyla ilgili kısa bir bilgi verir:

“Bugün rakamları öğreneceğiz.".

Gözden Geçirme: Daha sonra öğretmen, öğrencilere Arapça 'daki rakamlar ile ilgili kısa bir bilgi verir. 


\section{Derse Geçiş:}

\section{Dersin İşlenişi:}

-illk olarak öğretmen öğrencilere aşağıdaki şarkıları dinletir.

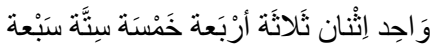

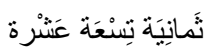

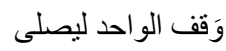

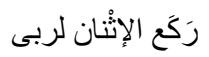

$$
\begin{aligned}
& \text { وثثلاثة واحد و الثنان } \\
& \text { و الأربعة اثنان و اثنان } \\
& \text { و الخمسة كَعْكة بالسكر } \\
& \text { و الستة وقفت لتنكّر } \\
& \text { و السبعة تنْظر للاعلى ولنى } \\
& \text { وثمانية عَكْس السبعة } \\
& \text { و عصا جدى مثل التسعة } \\
& \text { والصفر مع الو احد عثرة } \\
& \text { واحد اثنان ثلاثة اربعة خمسة سنة سبعة } \\
& \text { ثمانية تسعة عشرة }
\end{aligned}
$$

https://www.youtube.com/watch?v=WBCv9ZgzjqA

-Rakamlar harekeleriyle beraber tahtaya yazılır. Kendisiyle beraber öğrencilerin de yazmalarını ister.

-Şarkı tekrar dinletilir. Duyulan rakamların tekrar edilmesi istenir.

-Tekrar işlemi bittikten sonra öğrencilere şarkı tekrar dinletilir ve şarkı bittikten sonra tahtaya bakılarak şarkı söylenir.

-Tahtadaki rakamların okunuşları öğrenciler tarafından tekrar edilir.

-Şarkı hep beraber söylenir.

-Şarkıyı söylemek isteyen öğrencilere izin verilir.

\section{Uygulama 3}

\section{Sinif: 5}

Süre: 40 dakika

Kaynaklar / Araç Gereçler: tahta, tahta kalemi, akıllı tahta

Yöntem ve Teknikler: Anlatım yöntemi, soru-cevap tekniği, konuyla ilgili şarkının kullanımı

Ünite Ya Da Konunun Örüntüsü: Arapça renklerin öğretimi

\section{Hedefler:}

1. Verilen renkleri doğru telaffuz etme

2. Verilen renkleri ezbere bilme 


\section{Giriş Bölümü}

Dikkat Çekme: Öğretmen öğrencilere daha önceden Arapça renkleri duyup duymadıkları ile ilgili soru sorar.

Güdüleme: Öğretmen öğrencilere derste işleyecekleri konuyla ilgili kısa bir bilgi verir: "Bugün renkleri öğreneceğiz.".

Gözden Geçirme: Daha sonra öğretmen, öğrencilere Arapça' daki renkleri ile ilgili kısa bir bilgi verir.

\section{Derse Geçiş:}

\section{Dersin İşlenişi:}

-İlk olarak öğretmen öğrencilere aşağıdaki şarkıları dinletir.

$$
\begin{aligned}
& \text { أَلََّانْ } \\
& \text { نَحْنُ الألْوَان لا لالح لان لان }
\end{aligned}
$$

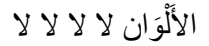

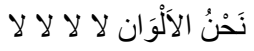

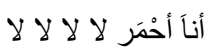

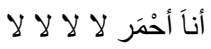

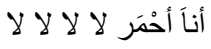

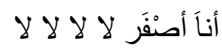

$$
\begin{aligned}
& \text { أنا أصفْرَ لا لا لا لا لا لا لا }
\end{aligned}
$$

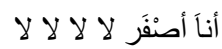

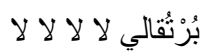

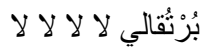

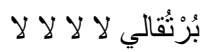

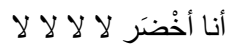

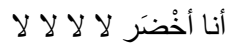

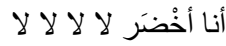

$$
\begin{aligned}
& \text { أنا أزْرَق لا لا لا لا لا لا لا } \\
& \text { أنا أزْرَق لا لا لا لا لا لا } \\
& \text { أنا أزْرَق لا لا لا لا لا لا }
\end{aligned}
$$

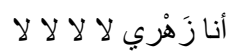

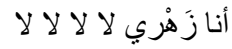

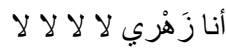

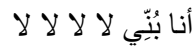

$$
\begin{aligned}
& \text { أنا يُنِّي لا لا لا لا لا لا لاني }
\end{aligned}
$$

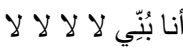

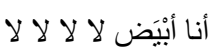

$$
\begin{aligned}
& \text { أنا أبيْضض لا لا لا لا لا لا لا لا لا } \\
& \text { أنا أبيْضض لا لا لا لا لا لا لا لا لا }
\end{aligned}
$$




$$
\begin{aligned}
& \text { أنا أسَوْد لا لا لا لا }
\end{aligned}
$$

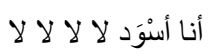

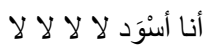

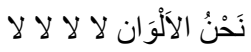

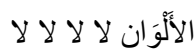

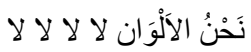

https://www.youtube.com/watch?v=zORUo6Lsns8\&t=39s

$$
\begin{aligned}
& \text { أُلْوان أُلْوان ألو ان ألُوان } \\
& \text { أحْمَر أحمَمَ أحمَمَ }
\end{aligned}
$$

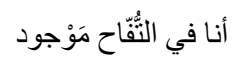

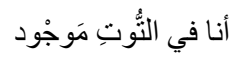

$$
\begin{aligned}
& \text { أحْمَر أحمَمَ أحمَمَ }
\end{aligned}
$$

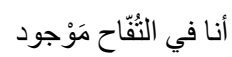

$$
\begin{aligned}
& \text { أنا في التُوتِ مَوجُود } \\
& \text { أحْمَر أحمَمَ أحمَّرَ }
\end{aligned}
$$

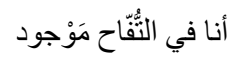

$$
\begin{aligned}
& \text { أنا في التُوتِتِ مَوجْود } \\
& \text { أخْضَرَ أخضضَرَ أخْضَر }
\end{aligned}
$$

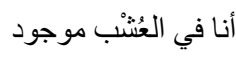

$$
\begin{aligned}
& \text { أنا في الثيَّجرَ موجود } \\
& \text { أخْضَرَ أخْضَرَ أخْضَر } \\
& \text { أنا في العُشْبَ موجود } \\
& \text { أنا في الثنَّجرَ موجود مرحد } \\
& \text { أصنْفر أصنْفر أصنْفر }
\end{aligned}
$$

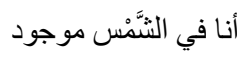

$$
\begin{aligned}
& \text { أنا في المَوْز موجود } \\
& \text { أصنْفر أصنْفر أصنْفر }
\end{aligned}
$$

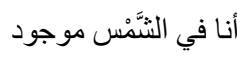

$$
\begin{aligned}
& \text { أنا في المَوْز موجود } \\
& \text { أزْرَق أزْرَقَ أزْرَق }
\end{aligned}
$$

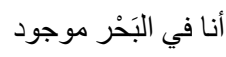

$$
\begin{aligned}
& \text { أنا في الستّماء موجود } \\
& \text { أزْرَق أَزْرَق أزْرَق }
\end{aligned}
$$

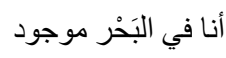

$$
\begin{aligned}
& \text { أنا في الستماء موجود }
\end{aligned}
$$

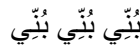

$$
\begin{aligned}
& \text { أنا في خَشْبَ موجود بِّي }
\end{aligned}
$$




$$
\begin{aligned}
& \text { أنا في الثُوكو لا موجود }
\end{aligned}
$$

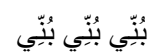

$$
\begin{aligned}
& \text { أنا في خَشْبْ موجود لِّد } \\
& \text { أنا في الثُوكو لا موجود } \\
& \text { وَرْدِي وَرْدي وَرْدي } \\
& \text { أنا في الزَّهَرْ موجود } \\
& \text { أنا في الحَلوى موجود الزهر مرجد } \\
& \text { وَرْدي وَرْدي وَرْدي } \\
& \text { أنا في الزََّّرْ موجود وردّد } \\
& \text { أنا في الحَلوى موجود الزّر مرجد } \\
& \text { أسموَد أسمْوَد أسْوَد } \\
& \text { أنا في الفَحْم موجود } \\
& \text { أنا في الليّل موجود } \\
& \text { أسْوَد أَسْوَد أسْوَد } \\
& \text { أنا في الفَفْم موجود } \\
& \text { أنا في الليّل موجود }
\end{aligned}
$$

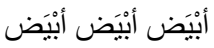

$$
\begin{aligned}
& \text { أنا في البَيْض موجود } \\
& \text { أنا في التُّج موجود }
\end{aligned}
$$

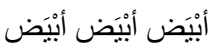

$$
\begin{aligned}
& \text { أنا في البَّضض موجود } \\
& \text { أنا في التَّج موجود } \\
& \text { ألْوَان ألُوان ألُ ان أُلْوان }
\end{aligned}
$$

\section{https://www.youtube.com/watch?v=AdQCja4MBcY}

-Renkler harekeleriyle beraber tahtaya yazılır. Kendisiyle beraber öğrencilerin de yazmaların istenir.

-Şarkı tekrar dinletilir. Duyulan renklerin tekrar edilmesi istenir.

-Tekrar işlemi bittikten sonra öğrencilere şarkılar tekrar dinletilir ve şarkılar bittikten sonra tahtaya bakılarak şarkılar söylenir.

-Tahtadaki renklerin okunuşları öğrenciler tarafından tekrar edilir.

-Şarkılar hep beraber söylenir.

-Şarkıları söylemek isteyen öğrencilere izin verilir. 


\section{EK-2 ARAPÇA DERSİ AKADEMIK BAŞARI TESTI}

1) Aşağıdaki seçeneklerden hangisinde Arapça harfler doğru sıralanmıştır?
A) $\dot{\tau}-\tau-\tau-\tau-\tau$
B) أ

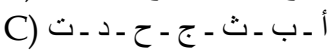
D)

2) Aşağıdaki seçeneklerin hangisinde peltek harfler doğru bir şekilde verilmiştir?
A) د-ن - د
B)
C) $د-w$
D) ش - د د

3) Verilen seçeneklerin arasından yanlış olanı seçiniz.

A) Arapça'da kendinden sonraki harfe birleşmeyen 6 adet harf vardır.

B) Arap alfabesinde 29 adet harf vardir.

C) Arap dili harflerinin çıkış yerleri farklılık gösterebilir.

D) Arapça'da peltek olarak okunan harfler vardir.

4) Aşağıdaki seçeneklerde harekeler ile ilgili bilgiler verilmiştir. Yanlış olan seçeneği işaretleyiniz.

A) Fetha harekesi harfe " $i$ " sesi verir.

B) Kesra harekesi harfe " $i$ " sesi verir.

C) Damme harekesi yazımı "

D) Harekeler Arap harflerine ses verirler.

5) Şedde harekesinin okunuşu ile ilgili hangi seçenekte hata yapılmıştır?
A) gitta
B) kettebe:

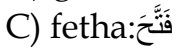
D) şedde: شَدَ
6) Aşağıdakilerden hangisinde aile fertlerinin Türkçe anlamı yanlış verilmiştir?

A) Anne: l
أب B) Baba

ج) Büyükanne: جدة

D) Kız kardeş : أخ :

7) Arapça rakamlar hangisinde doğru sıralama ile verilmiştir?
A) $r_{-} \varepsilon_{-} V_{-} D_{-} r_{-} r_{-} Y_{-} r_{-} q$
B) $1-r_{-} r_{-} \varepsilon_{-} O_{-} T_{-} Y_{-} \Lambda_{-} 9$
C) $1-r-\Delta_{-}-\varphi_{-} r_{-}-\Delta_{-}-\Delta_{-} r_{-} 9$
D) $1-Y_{-} Y_{-} \Delta_{-} Q_{-} Y_{-} \Lambda_{-} Y_{-} 9$

8) Hangi seçenekte yanlış verilmiş bir ifade vardir?
A) Dört: أربع
B) alt1 : ستع
واحد: dokuz
D) üç: ثلاث

9) Aşağıdakilerden hangisinde yapılan işlem yanlıştır?
A) $1+r=V$
B) $\varepsilon+r=r$
C) $\Delta+r=V$
D) $1+r=V$

10) Verilen şıkların hangisinde çekirdek aile üyeleri doğru bir şekilde verilmiştir?

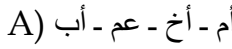

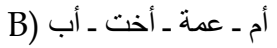

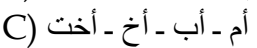

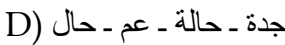

11) Aşağıdaki kelimelerden hangisi aile fertlerinden değildir?
A) أُ
B) أَبّْ
C)
D) حَدَّةُ

12) Aşağıdakilerden hangisi annemizin erkek kardeşidir?
A) مُدِيرِ
C) طَالِبِْ
B) خَال
D) عَعَّة

13) Türk bayrağımızın renkleri hangi seçenekte doğru verilmiştir?

Özcan, Ş., \& Yıldız, M. (2020). Müzik dinlemenin Arapça öğretiminde kullanılmasının öğrencinin akademik başarısına etkisi. Gazi Ĕ̆itim Bilimleri Dergisi, 6(3), 261-276.

DOI: https://dx.doi.org/110.30855/gjes.2020.06.03.001

Dergi Web Sayfast: http://dergipark.gov.tr/gebd 


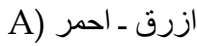
B) أحمر - أبيض أبضر

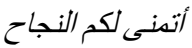
أسود - أبيض) - (أمبر

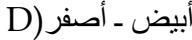
14)

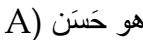

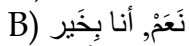

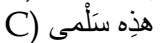

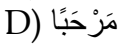

مَنْ هو؟

15) Hangi kelimenin Türkçe karşılığı yanlış verilmiştir?
A) $\mathrm{El}:$
B) Baş : رأس :
قدم: Ayak
D) Parmak : أسنان

16)

هَلْ أنتْتَ بِخَيْر؟
A) نَعَمْ أنا بِخَيَ
B) أهْلًَ بكِك
هذهِه سَلْمى (ن)
D) مَرْحَبً

17) Aşağıdaki eşleştirmelerden hangisi yanlıştır?

\begin{tabular}{|l|l|l|}
\hline $\mathbf{1}$ & Kirmız1 & أحمر \\
\hline $\mathbf{2}$ & Mavi & أصفر \\
\hline $\mathbf{3}$ & Sar1 & بني \\
\hline $\mathbf{4}$ & Mor &
\end{tabular}
A) 1
B) 2
C) 3
D) 4

18) Aşağıda verilen vücudumuzun bölümleri arasından hangisi başımızda yer almaz?
A) عَيْن
B) أَنْفن
فَ'
D)

19) Aşağıda verilen organlardan hangisi görmemizi sağlar?
A) قَََْ
B) بَطْن
C) عَبْن
D) رَأْسَن

Sınav bitmiştir. Birinci sorunun doğru cevabı 10, diğer soruların doğru cevabı 5 puandir. 